Eur. J. Clin. Chem. Clin. Biochem.

Vol. 32, 1994, pp. 705-707

(c) 1994 Walter de Gruyter \& Co.

Berlin - New York

\title{
Measurement of Salivary Insulin-Like Growth Factor-I in Acromegaly: Comparison with Serum Insulin-Like Growth Factor-I and Growth Hormone Concentrations
}

\author{
By S. Halimi ${ }^{1}$, D. Tepavčević ${ }^{1}$, D. Suchanek ${ }^{2}$, Z. Giljević ${ }^{1}$, Vesna Plavšić ${ }^{1}$ and M. Koršić ${ }^{1}$ \\ 1 Department of Endocrinology of Metabolism, Internal Clinic, Clinical Hospital Center, Zagreb, Croatia \\ 2 Department of Clinical Biochemistry and Reproductive Biology, University Clinic of Obstetrics and Gynecology, \\ Zagreb, Croatia
}

(Received February 2/June 8, 1994)

Summary: The aim of this study was to establish the concentration of insulin-like growth factor-I (IGF-I) in saliva of acromegalic patients, and to compare it with the basal levels of serum IGF-I and growth hormone. IGF-I was determined in extracted serum or neat saliva by a disequilibrium RIA using antibodies and iodinated ligand from Amersham and WHO $87 / 518$ as standard. The detection limit of the assay was $0.5 \mu \mathrm{g} / 1$, and the intra- and interassay coefficients of variations were $7.9 \%$ and $15 \%$ respectively. Our study included 13 healthy adult individuals and 17 acromegalics. Compared with healthy adult subjects, acromegalics had significantly higher salivary IGF-I concentrations (mean \pm SEM $5.4 \pm 2.64$ vs. $10.5+-5.69 \mu \mathrm{g} / \mathrm{l} ; \mathrm{p}<0.01)$, as well as serum IGF-I $(176 \pm 42.9$ vs. $520 \pm 98.8 \mu \mathrm{g} / \mathrm{l} ; \mathrm{p}<0.0001)$ and somatotropin levels $(1.2 \pm 1.02$ vs. $15.4 \pm 9.89 \mu \mathrm{g} / \mathrm{l} ; \mathrm{p}<0.0001)$. However, $47.1 \%$ patients ( 8 out of 17 ) with active acromegaly had salivary IGF-I concentrations within the normal range. Serum IGF-I and somatotropin concentrations were found to follow more closely the disease activity after adenomectomy, compared with the concentrations of salivary IGF-I. These results suggest that the IGF-I levels in serum and saliva are somatotropin-dependent. According to our results, measurement of IGF-I in saliva cannot be considered as an additional measure for evaluation of the disease activity in acromegaly, being less reliable than the determination of IGF-I and somatotropin in serum.

\section{Introduction}

Circulating concentrations of IGG-I are dependent on the rate of growth hormone (somatotropin) secretion, being low in hypopituitary and high in acromegalic patients $(1$, 2). Unlike insulin, IGF-I in the circulation (originating mainly from liver), is bound to specific binding proteins (3) and consequentially present in much higher concentrations.

It has recently been reported $(4,5)$ that IGF-I in human mixed saliva is present in the free form only and that it could be a good measure for predicting the overall somatotropin status. Unlike lipophilic drugs or steroid hormones, which are plasma ultrafiltrates, it is assumed that the IGFs in saliva are derived from the salivary glands $(4,5)$. There is also immunohistochemical evi- dence that IGF-I is present in salivary glands of rats and mice (6).

The present study was undertaken to establish the value of IGF-I levels in the saliva of acromegalic patients and to compare it with serum IGF-I and somatotropin concentrations.

\section{Patients and Methods}

Patients

Thirteen healthy volunteers, 9 females and 4 males, aged 23-54 years, and 17 patients with active acromegaly, 13 females and 4 males, aged 29-62 years, were admitted for examination and studied after fully informed oral consent had been obtained. All acromegalic patients had elevated basal somatotropin concentrations that were not suppressed below $5 \mu \mathrm{g} /$ by an oral load of $100 \mathrm{~g}$ of glucose. An indwelling teflon cannula was inserted in the 
antecubital vein after overnight fasting at $8 \mathrm{a} . \mathrm{m}$., and two basal blood samples were obtained at 8.30 and 9 a.m.; after clotting, the blood was centrifuged at $1500 \mathrm{~g}$, and the serum was kept frozen at $-20^{\circ} \mathrm{C}$ until analysed. Free flowing mixed saliva $(5 \mathrm{ml})$ was then collected during a 30-min period, centrifuged for $10 \mathrm{~min}$ at $1500 \mathrm{~g}$ at room temperature, and stored at $-20^{\circ} \mathrm{C}$ until analysis. Before RIA, thawed saliva was centrifuged again and a clear, non-viscous sample was analysed. Some samples needed further centrifugation to obtain a clear, non-viscous saliva.

\section{Assays}

Serum samples for IGF-I determination were extracted according to the method of Daughaday et al. (7), with some modifications. Briefly, $0.1 \mathrm{ml}$ of serum were extracted with $0.4 \mathrm{ml}$ acidic ethanol (2 $\mathrm{mol} / 1 \mathrm{HCl}$, volume fraction 0.125 , in absolute ethanol). After centrifugation, $0.2 \mathrm{ml}$ of the supernatant were neutralized with 0.1 $\mathrm{ml} 0.684 \mathrm{~mol} / \mathrm{l}$ Tris. The mixture was centrifuged and $0.1 \mathrm{ml}$ of the supernatant was finally diluted with $0.4 \mathrm{ml} 0.025 \mathrm{~mol} / 1$ phosphate buffer, pH 7.6, with $1 \mathrm{~g} / \mathrm{l}$ gelatine and $0.21 \mathrm{NaN}_{3}$ (RIA buffer). In order to establish a sensitive and reliable method for IGF-I determination in serum and saliva, RIA was optimized with commercially available antibodies and iodinated ligand from Amersham International (UK), using a disequilibrium assay: $0.1 \mathrm{ml}$ of $1: 37.5$ diluted serum extract, pure mixed saliva or standard (WHO $87 / 518$ ) was incubated with $0.1 \mathrm{ml}$ of antibody solution (initial dilution of $1 ! 6400$ in RIA buffer) at $4{ }^{\circ} \mathrm{C}$ for $24 \mathrm{~h}$. After incubation, $0.1 \mathrm{ml}$ of iodinated IGF-I was added and the tubes were further incubated overnight for $16-18 \mathrm{~h}$ at $4^{\circ} \mathrm{C}$. Separation of the bound and free ligand was performed with $0.8 \mathrm{ml}$ of cold $\left(4^{\circ} \mathrm{C}\right)$ $200 \mathrm{~g} / 1 \mathrm{PEG} 6000$ in $0.025 \mathrm{~mol} / \mathrm{l}$ phosphate buffer, $\mathrm{pH} 7.2$, containing $0.2 \mathrm{~g} / 1 \mathrm{NaN}_{3}$, and centrifuged for $30 \mathrm{~min}, 3000 \mathrm{~g}$ at $4{ }^{\circ} \mathrm{C}$. This method of separation was comparable with a more tedious one using dextran coated charcoal, as described by the manufacturer, giving non-specific binding of about $5 \%$.

According to the manufacturer's data, cross reactivities of IGF-I antibodies with IGF-II and insulin as well as epidermal growth factor are negligible: crossreactivity with human IGF-II was $<0.5 \%$, a $50 \%$ displacement of ligand gave the insulin concentration of $2000 \mathrm{mU} / \mathrm{l}$, and $95.2 \mu \mathrm{g} / \mathrm{l}$ of epidermal growth factor did not differ from the standard zero value. Intra-assay coefficients of variation (CVs) for serum concentrations at 101, 273 and $540 \mu \mathrm{g} / \mathrm{l}$ $(n=20)$ were $6.4 \%, 4.0 \%$ and $5.7 \%$, and for salivary concentrations at $2.99,5.93$ and $13.7 \mu \mathrm{g} / \mathrm{l}(\mathrm{n}=20)$ they were $7.9 \%, 5.3 \%$ and $6.7 \%$, respectively. Interassay CVs for the same serum levels $(\mathrm{n}=9)$ were $9.3 \%, 8.5 \%$ and $8.9 \%$, and for salivary levels $(\mathrm{n}=7)$ $15.0 \%, 10.2 \%$ and $9.9 \%$, respectively. The standard curve covered the range $0.48-62 \mu \mathrm{g} / \mathrm{l}$, with an assay detection limit of $0.5 \mu \mathrm{g} / \mathrm{l}$. The addition test, in which IGF-I standard was added to serum or saliva, and the dilution test in which serum was diluted with saline and saliva with RIA buffer, produced lines that were parallel to the standard curve. With this system, both serum (after extraction) and salivary IGF-I concentrations can be determined with the same RIA. Growth hormone was determined with a commercially available RIA test manufactured by Diagnostic Products Corporation (CA, USA). The test is calibrated against WHO 66/217, WHO 80/ 505 and National Institutes of Health (NIH), NIAMDD-hGH-RP1. The assay detection limit was $0.5 \mu \mathrm{g} / \mathrm{l}$, and the intra- and interassay CVs were $6.9 \%$ and $8.4 \%$, respectively.

The results of hormone determinations represent the mean of duplicate determinations in blood collected at 9 a. m., or in mixed saliva.

\section{Statistical analysis}

For testing the between-group comparisons, Student's t test and tpaired test were used as appropriate. Pearson's $r$ was used for the analysis of correlation. Statistical significance of a two-tailed test for less than 0.05 was considered significant. All values are expressed as mean \pm SEM. Statgraphics 4.2 software was used for statistical analysis on an IBM compatible computer.

\section{Results}

With our system, no detectable IGF-I concentrations could be demonstrated in the presence of binding proteins (e. g. serum), but we were able measure IGF-I concentrations in extracted serum, or neat saliva. Recovery of ${ }^{125} \mathrm{I}$-labelled IGF-I added to serum was $99.9 \%$ $\pm 2.4 \%$ for normal, and $98.3 \% \pm 2.4 \%$ for acromegalic sera. Multiple centrifugations of saliva did not affect salivary IGF-I concentrations. Salivary IGF-I concentrations showed a marked variation when determined in three acromegalics once monthly during three consecutive months: saliva values ranged from 2.3 to $26.9 \mu \mathrm{g} / \mathrm{l}$, in contrast to serum values, which varied from 559.7 to $619.6 \mu \mathrm{g} / \mathrm{l}$.

The patients with active acromegaly had significantly higher salivary and serum IGF-I concentrations than the normals: $10.5 \pm 5.69$ vs. $5.4 \pm 2.64 \mu \mathrm{g} / 1(\mathrm{p}<0.01)$ and $520 \pm 98.8$ vs. $176 \pm 42.9 \mu \mathrm{g} / 1$ ( $\mathrm{p}<0.0001)$, respectively, as well as serum somatotropin concentrations: $15.4 \pm 9.89$ vs. $1.2 \pm 1.02 \mu \mathrm{g} / 1(\mathrm{p}<0.0001)$. However, eight out of $17(47.1 \%)$ active acromegalics had salivary IGF-I levels within the reference range. None of the active acromegalics had serum IGF-I or somatotropin within the reference range (fig. 1).

In the group of healthy individuals and those with acromegaly, no significant correlation between salivary IGFI and serum IGF-I or somatotropin was found. Nevertheless, in the combined group of healthy subjects and active acromegalics $(n=30)$, a significant correlation between serum and salivary IGF-I was observed: $\mathrm{r}=0.489, \mathrm{p}<0.01$; no correlation between salivary IGF-I and basal serum somatotropin concentrations was found.
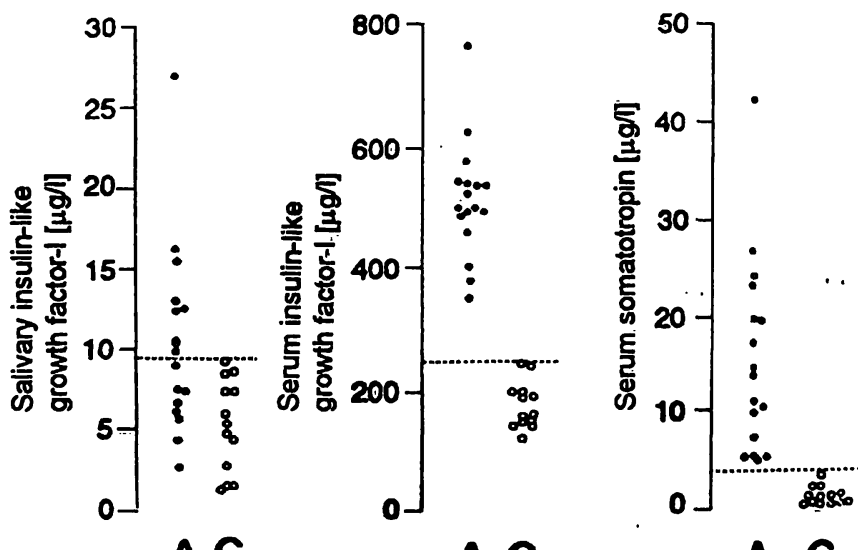

Fig. 1 Concentrations of salivary and serum insulin-like growth factor-I and serum somatotropin in patients with active acromegaly $(\mathrm{A})$ and in healthy control individuals $(\mathrm{C})$. The dashed line designates the upper limit of the values found in healthy subjects (controls). Acromegalics vs. controls: salivary IGF-I ( $p<0.01)$; serum IGF-I and somatotropin $(p<0: 0001)$. 
In five acromegalic patients before and after complete adenomectomy, serum IGF-I and somatotropin concentrations differed significantly $(p<0.005)$, in contrast to salivary IGF-I levels $(p>0.2)$ (tab. 1). Beside normal preoperative levels of salivary IGF-I, there was also a case of paradoxically increased salivary IGF-I concentration postoperatively.

\section{Discussion}

A sensitive RIA test for the determination of IGF-I concentrations in serum (after extraction) and saliva was designed. Within the same assay, serum and salivary IGF-I could be determined, making the evaluation of IGF-I levels in both samples more convenient.

Our results showed acromegalics to have significantly higher mean serum IGF-I and somatotropin concentrations and higher salivary IGF-I levels than the normal subjects. However, salivary IGF-I showed poor correlation with the disease activity; it was within the normal range in almost a half of the active acromegalics. Some patients had paradoxically low levels of salivary IGF-I, although they showed clear signs of disease activity, while serum IGF-I and somatotropin concentrations were well above the normal range. None of the active acromegalics had serum IGF-I or somatotropin concentration within the normal range. Measurement of sali-

Tab. 1 Hormone concentrations $(\mu \mathrm{g} / \mathrm{l})$ before and after adenomectomy for five patients with acromegaly ( $2-4$ weeks postoperatively).

\begin{tabular}{lccl}
\hline Hormone & $\begin{array}{l}\text { Preoperative } \\
\text { Mean } \pm \text { SEM }\end{array}$ & $\begin{array}{c}\text { Postoperative } \\
\text { Mean } \pm \text { SEM }\end{array}$ & $\mathrm{p}$ \\
\hline Salivary IGF-I & $8.7 \pm 1.40$ & $7.3 \pm 0.96$ & $>0.2$ \\
Serum IGF-I & $450 \pm 34.9$ & $188 \pm 23.4$ & $<0.05$ \\
Serum somatotropin & $9.7 \pm 1.48$ & $0.26 \pm 0.04$ & $<0.05$ \\
\hline
\end{tabular}

\section{References}

1. Furlanetto, R. W.. Underwood, L. E., Van Wyk, J. J. \& D'Ercole, A. J. (1977) Estimation of somatomedin-C levels in normals and patients with pituitary disease by radioimmunoassay. J. Clin. Invest. $60,648-657$.

2. Clemmons, R. R., Van Wyk, J. J., Ridgway, E. C., Kliman, B., Kjellberg, R. N. \& Underwood, L. E. (1979) Evaluation of acromegaly by radioimmunoassay of somatomedin-C. N. Engl. J. Med. 301, 1138-1142.

3. Hintz, R. L. \& Liu, F. (1977) Demonstration of specific plasma protein binding sites for somatomedin. J. Clin. Endocrinol. Metab. 45, 988-995.

4. Costigan, C. D., Guyda, H. J. \& Posner, B. I. (1988) Free insulin-like growth factor I (IGF-I) and IGF-II in human saliva. J. Clin. Endocrinol. Metab. 66, 1014-1018.

5. Ryan, J., Mantle, T. \& Costigan, D. C. (1992) A normal population study of human salivary insulin-like growth factor 1 (IGF 1) concentrations from birth through puberty. J. Clin. Endocrinol. Metab. 74, 774-778.

6. Hansson, H.-A. \& Tunhall, S. (1988) Epidermal growth factor and insulin-like growth factor I are localized in different com- vary IGF-I levels postoperatively showed no advantage over the determination of serum IGF-I and somatotropin concentrations.

Costigan et al. (4) also found a statistically significant difference between normal subjects and active acromegalics for both serum and salivary IGF-I levels. Whereas the ratio of mean salivary IGF-I levels in their acromegalics and normal subjects was 7.5 , in our study it was 1.9. The results with our RIA system showed serum IGF-I to be a much more reliable quantity in the evaluation of the disease activity than salivary IGF-I levels. Nevertheless, comparison of the levels of IGF-I in serum and saliva of normal subjects and acromegalic patients pointed to a significant positive linear correlation. Differences between these two studies could be due to the use of different standards, antibodies and conditions for RIA, contributing to unavoidable variations in the concentrations of IGF-I in serum and saliva.

A disadvantage of saliva as a sample may arise from the fact that it is an open system where the concentration of IGF-I may depend on the IGF-I content of the gland during salivation. A marked biological variation, as shown in this study, and the patient's hydration level (4) could further decrease the salivary IGF-I value in acromegalics. In contrast, serum is a defined system with a long half-life (several hours) of IGF-I (8) due to association with its binding proteins (3), and is less influenced by the patient's hydration condition. Finally, the liver may be a more appropriate target organ for the action of growth hormone than the salivary gland, which could be more liable to various undefined influences.

In conclusion, the measurement of IGF-I levels in saliva of acromegalics cannot be considered as an additional, useful quantity for evaluation of the disease activity in acromegaly, because it does not adequately mirror the corresponding serum levels.

partments of salivary gland duct cells. Immunohistochemical evidence. Acta Physiol. Scand. 134, 383-389.

7. Daughaday, W. H., Mariz, I. K. \& Blethen, S. L. (1980) Inhibition of access of bound somatomedin to membrane receptor and immunobinding sites: A comparison of radioreceptor and radioimmunoassay of somatomedin in native and acid-ethanol-extracted serum. J. Clin. Endocrinol. Metab. 51, 781-788.

8. Guler, H.-P., Zapf, J., Schmid, C. \& Froesch, R. E. (1989) Insulin-like growth factors I and II in healthy man. Estimations of half-lives and production rates. Acta Endocrinol. (Copnh.) 121, 753-758.

Prof. Dr. Danilo Tepavčević

Department of Internal Medicine

University School of Medicine

Zagreb Clinical Hospital

Kišpatićeva 12

41000 Zagreb

Croatia 
